\title{
Metformin, mitochondria and cancer
}

\author{
Navdeep S Chandel \\ From Metabolism, Diet and Disease 2014: Cancer and metabolism \\ Washington DC, USA. 28-30 May 2014
}

Most cancers have intact mitochondria function and we previously showed that mitochondria metabolism and ROS is essential for tumorigenesis. However, there are a subset of cancers which arise from mutations which abolish activity of TCA cycle enzymes, including Fumarate Hydratase $(\mathrm{FH})$ deficient renal cancer cells. While oxygen consumption is severely reduced in $\mathrm{FH}$ deficient human cancer cells, we uncovered that they are still dependent on mitochondrial metabolism and ROS for cell proliferation. Based on these results we propose that mitochondrial metabolism and/or ROS could be an attractive target for therapy. We will discuss the role of mitochondria in regulating cancer and how metformin might exert its anti-tumorigenic properties by inhibiting certain aspects of mitochondrial function.

Published: 28 May 2014

doi:10.1186/2049-3002-2-S1-027

Cite this article as: Chandel: Metformin, mitochondria and cancer.

Cancer \& Metabolism 2014 2(Suppl 1):O27.

Submit your next manuscript to BioMed Central and take full advantage of:

- Convenient online submission

- Thorough peer review

- No space constraints or color figure charges

- Immediate publication on acceptance

- Inclusion in PubMed, CAS, Scopus and Google Scholar

- Research which is freely available for redistribution

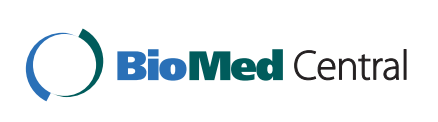

(C) 2014 Chandel; licensee BioMed Central Ltd. This is an Open Access article distributed under the terms of the Creative Commons Attribution License (http://creativecommons.org/licenses/by/4.0), which permits unrestricted use, distribution, and reproduction in any medium, provided the original work is properly cited. The Creative Commons Public Domain Dedication waiver (http:// creativecommons.org/publicdomain/zero/1.0/) applies to the data made available in this article, unless otherwise stated. 